\title{
THE PERSPECTIVE OF JAPAN HOME COUNTRY COMPANY TO THE PERFORMANCE EVALUATION OF SUBSIDIARIES COMPANY IN INDONESIA
}

\author{
Sherly Octaviani \\ Departement of Management FEB UMM \\ E-mail: $\underline{\text { shallyocta@gmail.com }}$
}

\begin{abstract}
The purpose of this study is to determine the financial performance of subsidiaries of Japanese multinationals operating in Indonesia from the perspective of the Japanese parent company and to find out which one of the company's financial performance had morehealthy during the year 2010 until 2012. The analytical tool used in this study to translate is to use the current rate method, and the analytical tools used to measure the financial performance of subsidiaries of multinational Japanese was by using financial ratio analysis, and to reject the measure using the method of time series and cross section.The result show that there was conducted on the financial report of a subsidiaries of the Japanese multinational operating in Indonesia by limiting the study period from 2010 until 2012. Based on the financial results of the Japanese multinational subsidiaries operating in Indonesia, which had been translated and analyzed it could be seen that the financial performed of multinational subsidiaries of the sub sectors of ceramic, glass and porcelain which operates in Indonesia in 2010 until 2012 indicate unhealthy conditions.
\end{abstract}

Keywords: Multinational corporation, translation of the financial statements, current rate method, exchange rate, ratio of financial.

\section{PENDAHULUAN}

Pada dasarnya kegiatan operasi perusahaan bertujuan untuk mencari profit atau laba, akan tetapi tidak hanya mendapatkan profit tetapi untuk memaksimalkan nilai perusahaan. Dalam menilai kinerja perusahaan biasanya dilihat dari laporan keuangan perusahaan. Kinerja perusahaan yang baik membuat kelangsungan hidup perusahaan dapat terus dipertahankan (going concern).
Kinerja perusahaan merupakan salah satu indikator yang penting, tidak saja bagi perusahaan, tetapi juga bagi investor. Kinerja keuangan menunjukkan kemampuan manajemen perusahaan dalam mengelola modalnya. Kinerja merupakan hasil yang telah dicapai atas berbagai aktivitas yang dilakukan dengan pendayagunaan berbagai sumber-sumber yang tersedia, yang digunakan dengan 
menggunakan ukuran tertentu yang standar.

Pengukuran kinerja digunakan perusahaan untuk melakukan perbaikan diatas kegiatan operasionalnya agar dapat bersaing dengan perusahaan lain. Analisis kinerja keuangan merupakan proses pengkajian secara kritis terhadap review data, menghitung, mengukur dan member solusi terhadap keuangan perusahaan pada suatu periode tertentu.

Perubahan perekonomian global secara manajerial diikuti juga oleh perubahan pada pengelolaan suatu usaha. Perusahaan yang ingin berhasil dalam pasar global harus mampu dengan cepat mengidentifikasikan dan memanfaatkan peluang yang ada, baik secara domestik maupun internasional. Salah satu cara yang dapat ditempuh adalah dengan memiliki operasi perusahaan anak atau cabang afiliasi yang berlokasi di negara lain, yang kemudian disebut sebagai perusahaan multinasional (Multinational Corporation-MNC).

Dalam pengapresiasi kontribusi Jepang pada hubungan ekonomi dengan Indonesia, tentu tidak bisa mengabaikan posisi dominan Jepang sebagai kreditor, mitra dagang dan investor terbesar di Indonesia. Keunikan keterkaitan antara investasi, dagang dan Official Development Assistance (ODA) senantiasa menarik perhatian. Pengaturan ODA cenderung memberi prioritas pada proyek yang bertalian dengan infrastruktur negara penerima bantuan, yang pada gilirannya dapat menjadi dasar bagi investasi (Widyahartono, 2003:267269).

Bagi Indonesia, Jepang merupakan negara mitra dagang terbesar dalam hal ekspor-impor Indonesia. Ekspor Indonesia ke Jepang bernilai US\$ 23.6 miliar (statistik Pemerintah RI), sedangkan impor Indonesia dari Jepang adalah US\$ 6.5 miliar sehingga bagi Jepang mengalami surplus besar impor dari Indonesia (tahun 2007). Komoditi penting yang diimpor Jepang dari Indonesia antara lain yaitu: minyak, gas alam cair, batubara, hasil tambang, udang, pulp, tekstil dan produk tekstil, mesin, perlengkapan listrik, dll.

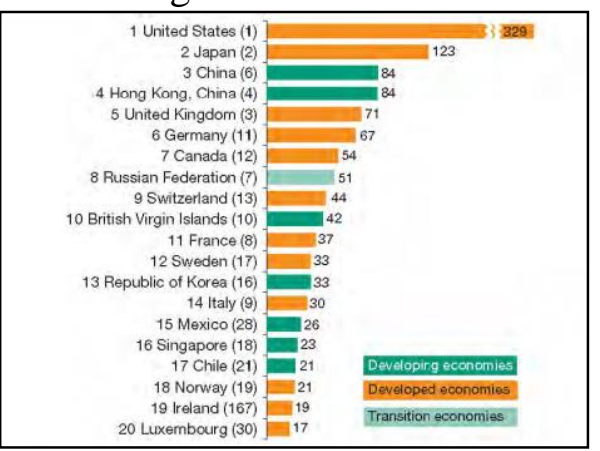

Gambar 1. Top 20 Investor Economies, 2012 (Dalam miliar dolar) Sumber: UNCTAD, World Investment Report 2013

Investasi Asing Langsung (Foreign Direct Investment-FDI) dari negara maju meningkat tajam pada tahun 2011, yaitu sebesar 25 persen dengan mencapaian USD 1.24 triliun. Uni Eropa, Amerika Utara 
dan Jepang memberikan kontribusi terhadap peningkatan ini. Dalam jajaran investor atas, Jepang menduduki peringkat kedua setelah Amerika Serikat pada tahun 2012.

Pada tahun 2012 jumlah realisasi investasi Perusahaan asal Jepang di Indonesia menduduki peringkat kedua, di bawah Singapura, dengan nilai USD 2.5 miliar atau 10 persen dari keseluruhan investasi asing yang sebesar USD 24.6 miliar, setara dengan $\mathrm{Rp} 221.0$ triliun. Di tahun 2012, realisasi investasi perusahaan Jepang di Indonesia ditujukan untuk perluasan bisnis perusahaan yang sudah beroperasi di Indonesia, khususnya guna memenuhi naiknya jumlah permintaan, dan juga perusahaan manufaktur skala menengah, untuk memasok komponen pabrikan besar, yang telah lebih dulu beroperasi diIndonesia (www.halojepang.com).

Tabel di bawah ini menunjukkan penjualan bersih perusahaan yang mengalami peningkatan dari tahun $2010 \mathrm{~s} / \mathrm{d}$
2012, tetapi untuk perusahaan dari sektor tekstil mengalami penurunan di tahun 2012. Berdasarkan laporan keuangan dalam rupiah, hal ini menunjukkan kinerja yang cukup baik, jika laporan keuangan anak perusahaan tersebut ditranslasikan ke perusahaan induk (mata uang induk), maka akan ada pengaruh dari nilai tukarnya.

Berdasarkan uraian tersebut, penulis tertarik untuk menganalisis dan mengetahui kinerja keuangan anak perusahaan multinasional Jepang di Indonesia. Dengan demikian penulis mengangkat judul "Evaluasi Kinerja Keuangan Anak Perusahaan Multinasional Jepang yang Beroperasi di Indonesia Dari Perspektif Perusahaan Induk Jepang".

\section{TINJAUAN PUSTAKA}

Manasikana (2008) yang meneliti anak perusahaan MNC yang bergerak pada bidang Tekstil danProduk Tekstil (TPT) di Indonesia, kinerja keuangan menggunakan

Tabel 1 Penjualan Bersih Anak Perusahaan Multinasional Jepang di Indonesia

\begin{tabular}{lrrr}
\hline \multicolumn{1}{c}{ Perusahaan } & \multicolumn{3}{c}{ Penjualan Bersih } \\
& \multicolumn{1}{c}{2012} & \multicolumn{1}{c}{ (Dalam Jutan Rupiah) } \\
\hline PT. Asahimas Flat Glass Tbk & 2.857 .310 & 2.596 .271 & \multicolumn{1}{c}{2.426 .138} \\
PT. Century Textile Industry Tbk & 275.300 & 369.054 & 249.409 \\
PT. Hexindo Adiperkasa Tbk & 6.495 .496 & 4.521 .370 & 3.067 .683 \\
PT. Mandom Indonesia Tbk & 1.851 .153 & 1.654 .671 & 1.466 .939 \\
PT. Surya Toto Indonesia Tbk & 1.576 .763 & 1.341 .927 & 1.121 .499 \\
PT. Taisho Pharmaceutical Indonesia Tbk & 387.535 & 341.815 & 305.251 \\
PT. Tembaga Mulia Semanan Tbk & 6.296 .300 & 6.067 .107 & 4.275 .538 \\
PT. Unitex Tbk & 147.566 & 206.178 & 164.593 \\
\hline
\end{tabular}

Sumber: Laporan Tahunan (www.idx.co.id)

analisis rasio dengan metode tolok ukur time series dan proses translasi dengan menggunakan metode current rate. Kesimpulan dari 
penelitian ini adalah hasil evaluasi kinerja keuangan anak MNC yang bergerak pada bidang Tekstil dan Produk Tekstil (TPT) di Indonesia pada periode 2005 s/d 2007 menunjukkan kinerja yang tidak sehat.

Hariyana (2012) yang meneliti perusahaan anak MNC Jepang yang beroperasi di Indonesi, kinerja keuangan menggunakan analisis rasio dengan metode tolok ukur time series dan proses translasi menggunakan metode current rate. Kesimpulan dari penelitian ini adalah hasil evaluasi kinerja keuangan anak MNC Jepang yang beroperasi di Indonesia pada periode 2009 s/d 2011 menunjukkan kinerja yang tidak sehat.

Penelitian ini menggunakan metode analisis rasio keuangan dengan metode tolok ukur cross section dan time series. Metode translasi yang digunakan adalah metode current rate.Kinerja keuangan perusahaan pada dasarnya diperlukan sebagai alat untuk mengukur financial health (kesehatan keuangan) perusahaan. Kinerja keuangan perusahaan digunakan sebagai media pengukuran subyektif yang menggambarkan efektifitas penggunaan aset oleh sebuah perusahaan dalam menjalankan bisnis utamanya dan meningkatkan pendapatan.

Menurut Al-Tuwajiri, et al (2003), kinerja keuangan perusahaan secara umum dapat dilihat dari dua ukuran, yaitu: (1) Market-based measure, Menurut jones (2004), return dari sebuah saham merupakan salah satu tolak ukur dari kinerja saham sehingga para investor selalu berusaha memaksimalkan tingkat return yang akan dihasilkan setelah memperhitungkan faktor risiko. Return juga merupakan hasil ataupun keuntugan yang didapat dari proses investasi yang dapat digunakan untuk memotivasi investor dalam berinvestasi.dan (2)Accountingbased measure, Dasar pemikiran accounting-based measure ini adalah fokus terhadap reaksi pendapatan perusahaan terhadap perubahan kebijakan yang diambil oleh manajemen. Dengan kata lain, pengukuran return akuntansi ini adalah berdasarkan kondisi financial internal perusahaan tanpa memperhitungkan faktor eksternal.

Menurut

Ambarwati (2010:238) perusahaan multinasional adalah perusahaan yang terlibat dalam produksi dan penjualan barang-barang dan jasa-jasa di lebih dari satu negara. Perusahaan multinasioal biasanya terdiri atas perusahaan induk yang berada di negara asal dan memiliki beberapa cabang perusahaan atau anak perusahaan yang berada di luar negeri.

Terdapat enam alasan penting kenapa perusahaan melakukan Go Internasional, yaitu: memperluas pasar, mempertahankan kelangsungan supply bahan baku, penguasaan teknologi, peningkatan efesiensi produksi, menghindari hambatan politik dan peraturan pemerintah, dan memperkecil risiko bisnis (Sartono, 2003:2).

Sebuah perusahaan Induk dan anak perusahaannya (anak cabang) adalah entitas hukum terpisah dan entitas akuntansi terpisah karenanya catatan akuntansi terpisah dipertahankan dan laporan keuangan 
terpisah dikeluarkan. Namun karena para pemegang saham induk juga mengontrol (melalui induk) anak cabang (subsidiary), perusahaan gabungan ini diperlakukan sebagai suatu entitas akuntansi tunggal (Tangkilisan, 2003:15).

Dalam penyusunan laporan keuangan konsolidasi dibutuhkan aktivitas translasi atau penilaian uang atas aktiva, kewajiban, penerimaan biaya dan laba atau rugi. Pada saat melakukan translasi, perusahaan bisa saja mengalami keuntungan maupun kerugian yang disebabkan oleh mata uang asing yang digunakan. Keuntungan ataupun kerugian translasi ini akan terjadi jika nilai tukar pada akhir tahun operasi berbeda dengan awal tahunnya.

Nilai tukar (exchange rate) adalah nilai (harga) mata uang suatu Negara yang dinilai dengan mata uang negara lainnya. Nilai tukar biasanya berubah secara relatif konstan. Nilai tukar yang ditampilkan sebelumnya dikenal sebagai nilai tukar sekarang (spot rate, atau kurs spot), yang berarti nilai tukar yang dibayarkan penerimaan mata uang "pada saat itu" atau pada kenyataannya, tidak lebih dari dua hari setelah hari perdagangan

(Ambarwati, 2010:241).

Terdapat dua metode dasar bagi translasi laporan keuangan anak perusahaan di luar negeri yang digunakan di seluruh dunia (Eiteman, 2010:307), yaitu: metode nilai tukar saat ini (current rate method) dan Metode temporal (temporal method).

Metode nilai tukar saat ini (current rate method) merupakan metode yang paling lazim di dunia pada saat ini. Dengan metode ini, lini item pada laporan keuangan ditranslasikan menurut nilai tukar "saat ini (current)", dengan beberapa pengecualian. Lini itemnya mencangkup: (1) Aset dan kewajiban, seluruh asset/aktiva dan kewajiban ditranslasikan pada nilai tukar saat ini, yakni nilai tukar yang berlaku pada tanggal neraca, (2)Item laporan laba-rugi, seluruh item, (3)Distribusi, Dividen yang dibayarkan ditranslasikan pada nilai tukar yang berlaku pada saat tanggal pembayaran, (4)Item Ekuitas, akun saham biasa dan modal disetor ditranslasikan pada nilai tukar historis. Laba ditahan akhir tahun terdiri dari laba ditahan awal tahun, plus atau minus laba atau rugi untuk tahun tersebut.

Metode temporal, dengan metode temporal, aset dan kewajiban tertentu ditranslasikan pada nilai tukar yang konsisten dengan waktu penciptaan item-item keuangan itu. Metode temporal mengasumsikan bahwa sejumlah lini item asset individual seperti persediaan dan peralatan dan pabrik bersih dinyatakan ulang secara berkala untuk mencerminkan nilai pasar.

Jika item-item ini tidak dinyatakan ulangnamun sebaliknya dinyatakan dalam biya historis, metode temporal menjadi metode moneter/nonmoneter dari translasi, suatu bentuk translasi yang masih digunakan oleh sejumlah negara saat ini. Lini itemnya termasuk: (1) Aset moneter, (2) Aset dan kewajiban moneter, (3) Item laporan laba-rugi, (4)Distribusi, (5)Item ekuitas.

Analisis laporan keuangan penting dilakukan untuk mengetahui kekuatan dan kelemahan suatu perusahaan. Informasai ini 
diperlukan untuk mengevaluasi kinerja yang dicapai manajemen perusahaan di masa yang lalu, dan juga untuk bahan pertimbangan dalam menyusun rencana perusahaan ke depan. Salah satu cara memperoleh informasi yang bermanfaat dari laporan keuangan perusahaan adalah dengan melakukan analisis rasio keuangan.

Rasio keuangan didesain untuk memperlihatkan hubungan antar akun pada laporan keuangan (Sudana, 2011:20).Menurut Sudana (2011:20-24), terdapat 5 jenis rasio keuangan, yaitu: (1)rasio likuiditas, (2)rasio aktivitas, (3)rasio penilaian pasar, (4)rasio profitabilitas, dan (5)rasio solvabilitas.

\section{METODE PENELITIAN}

Jenis penelitian yang digunakan adalah jenis penelitian deskriptif, yaitu jenis penelitian yang bertujuan untuk menjelaskan karakteristik suatu fenomena yang dapat digunakan sebagai dasar pembuatan keputusan untuk memecahkan masalah.

Data yang digunakan dalam penelitian ini adalah data kuantitatif. Data yang dipergunakan adalah laporan keuangan tahunan perusahaan periode 2010 s/d 2012.Sumber data adalah subjek dari mana data dapat diperoleh (Arikunto, 2006:129). Dalam penelitian ini data diperoleh dan dikumpulkan dari www.idx.co.idyang berupa laporan keuangan perusahaan. Menurut Arikunto (2006:130), populasi adalah keseluruhan objek penelitian. Populasi pada penelitian ini adalah seluruh perusahaan dengan Penanam Modal Asing (Foreign Direct Investment-FDI) Jepang yang tercatat di Bursa Efek Indonesia (BEI) periode 2010 s/d 2012.

Sampel adalah sebagian atau wakil populasi yang diteliti Menurut (Arikunto, 2006:131). Penelitian sampel dalam penelitian ini menggunakan purposive sampling yaitu sampel yang dipilih berdasarkan atas adanya tujuan dan pertimbangan tertentu. Pengambilan sampel yang digunakan adalah pada perusahaan sub sektor. Alasan penulis dalam pengambilan sampel pada penelitian ini adalah: (1) Perusahaan tersebut bergerak pada sub sektor yang sama yaitu: sub sektorceramic, glass and porcelain, (2)Perusahaan tersebut memiliki laporan keuangan berturut-turut selama tiga tahun terakhir (2010 s/d2012) dan telah dipublikasikan oleh Bursa Efek Indonesia (BEI).Dalam memperoleh data untuk penulisan penelitian ini, penulis menggunakan metode dokumentasi. Dokumen yang dikumpulkan berupa laporan keuangan dan laporan tahunan perusahaan yang telah dipublikasikan oleh Bursa Efek Indonesia (BEI) dan kurs tukar mata uang yang dikeluarkan oleh Bank Indonesia (BI).

Analisis data dilakukan setelah peneliti mengumpulkan semua data yang diperlukan dalam penelitian. Peneliti melakukan beberapa langkah persiapan untuk memudahkan proses analisis data dan interpretasi hasilnya. Adapun langkah-langkah dalam menganalisis data adalah sebagai berikut: (1)Mengumpulkan data-data berupa laporan keuangan anak perusahaan multinasional jepang yang beroperasi di Indonesia, (2)Mentranslasikan laporan keuangan perusahaan 
yangtelah ditetapkan sebagai sampel penelitian ke mata uang perusahaan induk Jepang. Dalam penelitian ini, metode translasi yang akan digunakan adalah current rate method. Mata uang yang dipergunakan adalah Yen (¥), (3) Menganalisis kinerja perusahaan menggunakan metode rasio keuangan, (4) Menentukan kinerja anak perusahaan multinasional Jepang menggunakan metode time series dan cross section.

\section{HASIL PENELITIAN DAN PEMBAHASAN}

Berdasarkan tabel Hasil

Analisis Rasio Keuangan PT.
2010 s/d 2012 secara lintas waktu (time series) diatas yang terdapat pada tabel 2, diperoleh hasil analisis penelitian yang menunjukkan bahwa pada tahun 2010 s/d 2011 perhitungan rasio yang dinyatakan lebih sehat sebanyak 9 rasio, 1 rasio dinyatakan tetap dan yang dinyatakan lebih tidak sehat sebanyak 9 rasio. Pada tahun 2011 s/d 2012 perhitungan rasio yang dinyatakan lebih sehat sebanyak 5 rasio, 1 rasio dinyatakan tetap sdan yang dinyatakan lebih tidak sehat sebanyak 13 rasio. Secara umum, kinerja keuangan perusahaan sepanjang tahun 2010 s/d 2012 dinyatakan lebih tidak sehat.

Asahimas Flat Glass, Tbk. Tahun

Tabel 2. Hasil Analisis Rasio Keuangan PT. Asahimas Flat Glass, Tbk.

Tahun 2010 s/d 2012 Secara Lintas Waktu (Time Series)

\begin{tabular}{|c|c|c|c|c|c|c|}
\hline \multirow[t]{2}{*}{ Rasio Keuangan } & \multicolumn{3}{|c|}{$\begin{array}{l}\text { Perbandingan Tingkat Kesehatan } \\
\text { Rasio Pada Tahun } 2010 \text { s/d } 2011\end{array}$} & \multicolumn{3}{|c|}{$\begin{array}{l}\text { Perbandingan Tingkat Kesehatan } \\
\text { Rasio Pada Tahun } 2011 \mathrm{~s} / \mathrm{d} 2012\end{array}$} \\
\hline & 2010 & 2011 & Kesimpulan & 2011 & 2012 & Kesimpulan \\
\hline \multicolumn{7}{|l|}{ Rasio Likuiditas: } \\
\hline Rasio Lancar & $394 \%$ & $442 \%$ & Lebih Sehat & $442 \%$ & $389 \%$ & Lebih Tidak seh \\
\hline Rasio Cepat & $244 \%$ & $264 \%$ & Lebih Sehat & $264 \%$ & $231 \%$ & Lebih Tidak seha \\
\hline Rasio Kas & $166 \%$ & $176 \%$ & Lebih Sehat & $176 \%$ & $152 \%$ & Lebih Tidak seh \\
\hline \multicolumn{7}{|l|}{ Rasio Aktivitas: } \\
\hline Perputaran Persediaan & $5.18 x$ & $4.49 x$ & Lebih Tidak sehat & $4.49 x$ & $4.14 x$ & Lebih Tidak seh \\
\hline Perputaran Piutang & $10.58 x$ & $9.94 x$ & Lebih Tidak sehat & $9.94 x$ & $8.96 x$ & Lebih Tidak seh \\
\hline Perputaran Aset Tetap & $2.45 \mathrm{x}$ & $2.32 x$ & Lebih Tidak sehat & $2.32 x$ & $2.01 \mathrm{x}$ & Lebih Tidak seh \\
\hline Perputaran Jumlah Aset & $1.07 x$ & $0.99 \mathrm{x}$ & Lebih Tidak sehat & $0.99 x$ & $0.89 x$ & Lebih Tidak seh \\
\hline \multicolumn{7}{|l|}{ Rasio Penilaian Pasar: } \\
\hline PER & $726 \%$ & $821 \%$ & Lebih Sehat & $821 \%$ & $1069 \%$ & Lebih Sehat \\
\hline Dividend Yield & $1 \%$ & $1 \%$ & Tetap & $1 \%$ & - & Lebih Sehat \\
\hline DPR & $10 \%$ & $10 \%$ & Lebih Sehat & $10 \%$ & - & Lebih Sehat \\
\hline Market to Book Ratio & $130 \%$ & $129 \%$ & Lebih Tidak sehat & $129 \%$ & $151 \%$ & Lebih Sehat \\
\hline \multicolumn{7}{|l|}{ Rasio Profitabilitas: } \\
\hline ROA & $15 \%$ & $13 \%$ & Lebih Tida & $13 \%$ & $11 \%$ & Lebih Tidak seh \\
\hline ROE & $153 \%$ & $155 \%$ & Lebih Sehat & $155 \%$ & $160 \%$ & Lebih Sehat \\
\hline \multicolumn{7}{|l|}{ Profit Margin Ratio: } \\
\hline Net Profit Margin & $14 \%$ & $13 \%$ & Lebih Tidak sehat & $13 \%$ & $12 \%$ & Lebih Tidak sehat \\
\hline OPM & $18 \%$ & $17 \%$ & Lebih Tidak sehat & $17 \%$ & $16 \%$ & Lebih Tidak seh \\
\hline Gross Profit Margin & $27 \%$ & $26 \%$ & Lebih Tidak sehat & $26 \%$ & $25 \%$ & Lebih Tidak seh \\
\hline \multicolumn{7}{|l|}{ Rasio Solvabilitas: } \\
\hline Debt to Capital A & $22 \%$ & $20 \%$ & Lebih $\mathrm{S}$ & $20 \%$ & $21 \%$ & Lebih Tidak seh \\
\hline Debt to Equity Ratio & $27 \%$ & $25 \%$ & Lebih Sehat & $25 \%$ & $28 \%$ & Lebih Tidak seh \\
\hline $\begin{array}{l}\text { Long Term Debt to } \\
\text { Equity Ratio }\end{array}$ & $11 \%$ & $10 \%$ & Lebih Sehat & $10 \%$ & $10 \%$ & Tetap \\
\hline
\end{tabular}

Sumber: Data diolah,2014 
Tabel diatas menunjukkan bahwa perbandingan tingkat kesehatan rasio keuangan pada tahun 2010 s/d 2011 dapat dikatakan cenderung lebih sehat dibandingkan dengan tingkat kesehatan rasio keuangan pada tahun 2011 s/d 2012. Hal ini dikarenakan kondisi keuangan perusahaan yang kurang stabil pada tahun 2012.

Hal ini disebabkan oleh kurangnya efisiensi perusahaan dalam mengelola aktivanya dari tahun 2010 s/d 2012. Hal ini juga disebabkan oleh kurangnya efesiensi perusahaan dalam menjalankan operasinya. Pada tahun 2011 s/d 2012 perusahaan juga mengalami penurunan pada rasio likuiditas, hal ini disebabkan karena berkurangnya kemampuan perusahaan untuk memenuhi kewajiban keuangan jangka pendek perusahaan.

Tabel 3 menunjukkan analisis rasio keuangan pada PT. Asahimas Flat Glass, Tbk secara cross section menunjukkan perbandingan yang cenderung lebih tidak sehat dibandingkan dengan rata-rata industri pada tahun 2010 s/d 2012.

Tabel 3. Hasil Analisis Rasio Keuangan PT. Asahimas Flat Glass, Tbk. Tahun 2010 s/d 2012 Secara Cross Section

\begin{tabular}{|c|c|c|c|c|c|c|}
\hline \multirow{2}{*}{ Rasio Keuangan } & \multicolumn{3}{|c|}{ Perusahaan } & \multicolumn{3}{|c|}{ Rata-Rata Industri } \\
\hline & 2010 & 2011 & 2012 & 2010 & 2011 & 2012 \\
\hline \multicolumn{7}{|l|}{ Rasio Likuiditas: } \\
\hline Rasio Lancar & $394 \%$ & $442 \%$ & $389 \%$ & $298.5 \%$ & $315 \%$ & $302 \%$ \\
\hline Rasio Cepat & $244 \%$ & $264 \%$ & $231 \%$ & $191.5 \%$ & $194.5 \%$ & $186 \%$ \\
\hline Rasio Kas & $166 \%$ & $176 \%$ & $152 \%$ & $112 \%$ & $112 \%$ & $98.5 \%$ \\
\hline \multicolumn{7}{|l|}{ Rasio Aktivitas: } \\
\hline Perputaran Persediaan & $5.18 \mathrm{x}$ & $4.49 x$ & $4.14 \mathrm{x}$ & $5.21 \mathrm{x}$ & $4.32 \mathrm{x}$ & $4.38 x$ \\
\hline Perputaran Piutang & $10.58 x$ & $9.94 x$ & $8.96 x$ & $7.38 \mathrm{x}$ & $7.08 \mathrm{x}$ & $6.31 x$ \\
\hline Perputaran Aset Tetap & $2.45 x$ & $2.32 \mathrm{x}$ & $2.01 \mathrm{x}$ & $2.85 x$ & $2.61 x$ & $2.67 x$ \\
\hline $\begin{array}{l}\text { Perputaran Jumlah } \\
\text { Aset }\end{array}$ & $1.07 \mathrm{x}$ & $0.99 x$ & $0.89 x$ & $1.08 x$ & $1.01 \mathrm{x}$ & $0.95 x$ \\
\hline \multicolumn{7}{|l|}{ Rasio Penilaian Pasar: } \\
\hline PER & $726 \%$ & $821 \%$ & $1069 \%$ & $839 \%$ & $962 \%$ & $1253 \%$ \\
\hline Dividend Yield & $1 \%$ & $1 \%$ & - & $2.5 \%$ & $2.5 \%$ & - \\
\hline DPR & $10 \%$ & $10 \%$ & - & $24 \%$ & $26 \%$ & - \\
\hline Market to Book Ratio & $130 \%$ & $129 \%$ & $151 \%$ & $211.5 \%$ & $223 \%$ & $264 \%$ \\
\hline \multicolumn{7}{|l|}{ Rasio Profitabilitas: } \\
\hline ROA & $15 \%$ & $13 \%$ & $11 \%$ & $17 \%$ & $15 \%$ & $13 \%$ \\
\hline ROE & $153 \%$ & $155 \%$ & $160 \%$ & $272.5 \%$ & $298.5 \%$ & $319 \%$ \\
\hline \multicolumn{7}{|l|}{ Profit Margin Ratio: } \\
\hline Net Profit Margin & $14 \%$ & $13 \%$ & $12 \%$ & $15.5 \%$ & $14.5 \%$ & $13.5 \%$ \\
\hline OPM & $18 \%$ & $17 \%$ & $16 \%$ & $20.5 \%$ & $19.5 \%$ & $19 \%$ \\
\hline $\begin{array}{l}\text { Gross Profit } \\
\text { Margin }\end{array}$ & $27 \%$ & $26 \%$ & $25 \%$ & $29 \%$ & $28 \%$ & $27.5 \%$ \\
\hline \multicolumn{7}{|l|}{ Rasio Solvabilitas: } \\
\hline $\begin{array}{l}\text { Debt to Capital Asset } \\
\text { Ratio }\end{array}$ & $22 \%$ & $20 \%$ & $21 \%$ & $32 \%$ & $31.5 \%$ & $31 \%$ \\
\hline Debt to Equity Ratio & $27 \%$ & $25 \%$ & $28 \%$ & $48.5 \%$ & $49.5 \%$ & $50 \%$ \\
\hline $\begin{array}{l}\text { Long Term Debt to } \\
\text { Equity Ratio }\end{array}$ & $11 \%$ & $10 \%$ & $10 \%$ & $13.5 \%$ & $13.5 \%$ & $15 \%$ \\
\hline
\end{tabular}


Berdasarkan tabel Hasil Analisis Rasio Keuangan PT. Surya Toto Indonesia, Tbk. Tahun 2010 s/d 2012 secara lintas waktu (time series) diatas yang terdapat pada tabel 4, diperoleh hasil analisis penelitian yang menunjukkan bahwa pada tahun 2010 s/d 2011 perhitungan rasio yang dinyatakan lebih sehat sebanyak 5 rasio, 1 rasio dinyatakan tetap dan yang dinyatakan lebih tidak sehat sebanyak 13 rasio. Pada tahun 2011 s/d 2012 perhitungan rasio yang dinyatakan lebih sehat sebanyak 10 rasio, yang dinyatakan tetap sebanyak 2 rasio dan yang dinyatakan lebih tidak sehat sebanyak 7 rasio. Secara umum, kinerja keuangan perusahaan sepanjang tahun 2010 s/d 2012 dinyatakan lebih tidak sehat.

Tabel 4. Hasil Analisis Rasio Keuangan PT. Surya Toto Indonesia, Tbk. Tahun 2010 s/d 2012 Secara Lintas Waktu (Time Series)

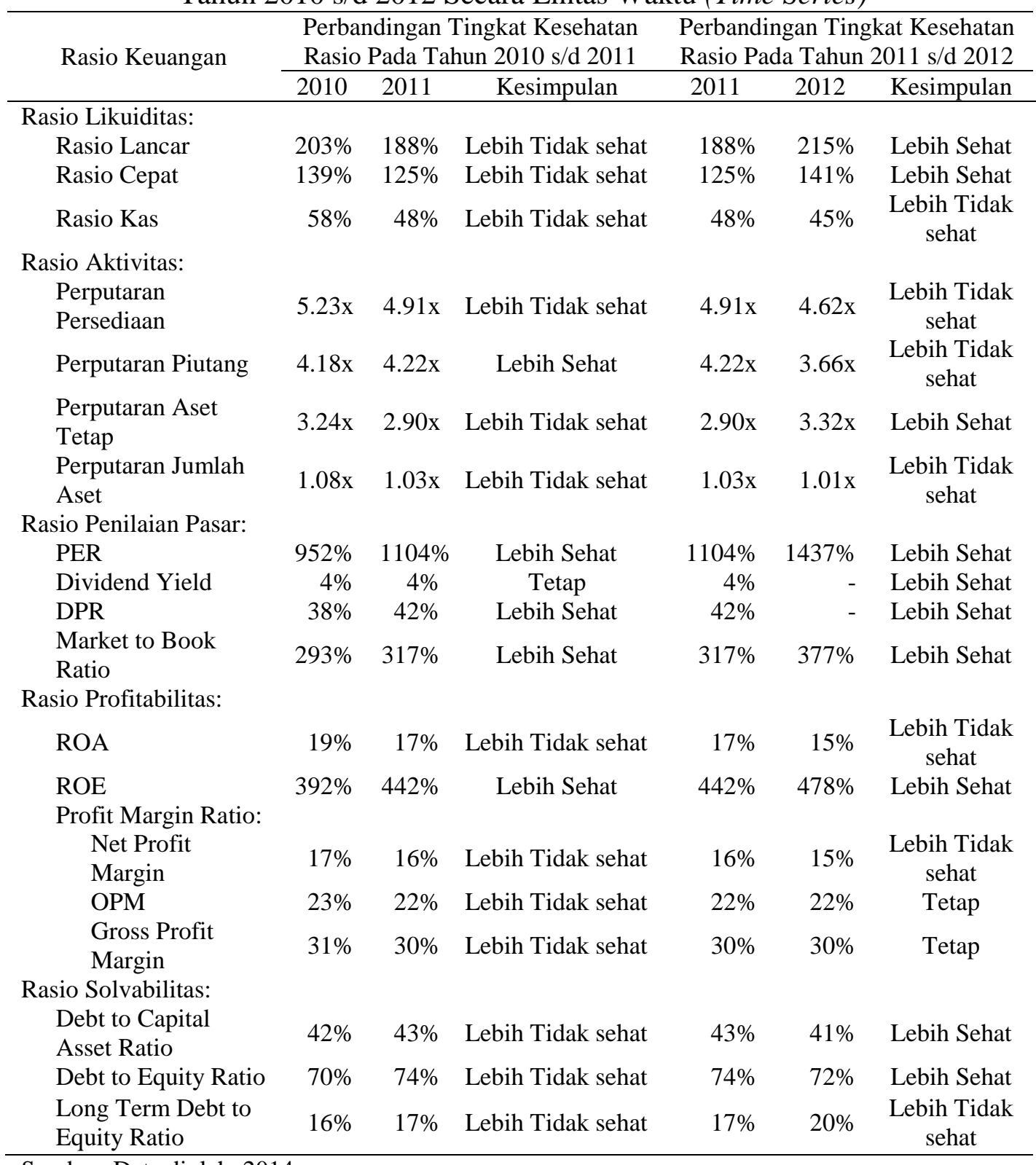


Hal ini disebabkan oleh kurangnya efisiensi perusahaan dalam mengelola aktivanya, juga kurangnya efesiensi perusahaan dalam menjalankan operasinya pada tahun $2010 \mathrm{~s} / \mathrm{d}$ 2011. Hal ini disebabkan juga karena rasio solvabilitas yang menunjukkan besarnya porsi penggunaan utang dalam membiayai investasi pada aktiva perusahaan pada tahun 2010 s/d 2011. Dibandingkan dengan tahun 2010 s/d 2011, pada tahun 2011 s/d 2012 perusahaan mengalami kinerja perusahaan yang lebih sehat.

Berdasarkan tabel 5, analisis rasio keuangan pada PT. Surya Toto Indonesia, Tbk secara cross section menunjukkan sehat dibandingkan dengan rata-rata industri pada tahun 2010 s/d 2012

Tabel 5. Hasil Analisis Rasio Keuangan PT. Surya Toto Indonesia, Tbk.

Tahun 2010 s/d 2012 Secara Cross Section

\begin{tabular}{|c|c|c|c|c|c|c|}
\hline \multirow{2}{*}{ Rasio Keuangan } & \multicolumn{3}{|c|}{ Perusahaan } & \multicolumn{3}{|c|}{ Rata-Rata Industri } \\
\hline & 2010 & 2011 & 2012 & 2010 & 2011 & 2012 \\
\hline \multicolumn{7}{|l|}{ Rasio Likuiditas: } \\
\hline Rasio Lancar & $203 \%$ & $188 \%$ & $215 \%$ & $298.5 \%$ & $315 \%$ & $302 \%$ \\
\hline Rasio Cepat & $139 \%$ & $125 \%$ & $141 \%$ & $191.5 \%$ & $194.5 \%$ & $186 \%$ \\
\hline Rasio Kas & $58 \%$ & $48 \%$ & $45 \%$ & $112 \%$ & $112 \%$ & $98.5 \%$ \\
\hline \multicolumn{7}{|l|}{ Rasio Aktivitas: } \\
\hline $\begin{array}{l}\text { Perputaran } \\
\text { Persediaan }\end{array}$ & $5.23 \mathrm{x}$ & $4.91 x$ & $4.62 x$ & $5.21 \mathrm{x}$ & $4.32 \mathrm{x}$ & $4.38 x$ \\
\hline Perputaran Piutang & $4.18 x$ & $4.22 \mathrm{x}$ & $3.66 \mathrm{x}$ & $7.38 \mathrm{x}$ & $7.08 x$ & $6.31 \mathrm{x}$ \\
\hline $\begin{array}{l}\text { Perputaran Aset } \\
\text { Tetap }\end{array}$ & $3.24 \mathrm{x}$ & $2.90 x$ & $3.32 \mathrm{x}$ & $2.85 x$ & $2.61 x$ & $2.67 x$ \\
\hline $\begin{array}{l}\text { Perputaran Jumlah } \\
\text { Aset }\end{array}$ & $1.08 \mathrm{x}$ & $1.03 \mathrm{x}$ & $1.01 \mathrm{x}$ & $1.08 x$ & $1.01 \mathrm{x}$ & $0.95 x$ \\
\hline \multicolumn{7}{|l|}{ Rasio Penilaian Pasar: } \\
\hline PER & $952 \%$ & $1104 \%$ & $1437 \%$ & $839 \%$ & $962 \%$ & $1253 \%$ \\
\hline Dividend Yield & $4 \%$ & $4 \%$ & - & $2.5 \%$ & $2.5 \%$ & - \\
\hline DPR & $38 \%$ & $42 \%$ & - & $24 \%$ & $26 \%$ & - \\
\hline $\begin{array}{l}\text { Market to Book } \\
\text { Ratio }\end{array}$ & $293 \%$ & $317 \%$ & $377 \%$ & $211.5 \%$ & $223 \%$ & $264 \%$ \\
\hline \multicolumn{7}{|l|}{ Rasio Profitabilitas: } \\
\hline ROA & $19 \%$ & $17 \%$ & $15 \%$ & $17 \%$ & $15 \%$ & $13 \%$ \\
\hline ROE & $392 \%$ & $442 \%$ & $478 \%$ & $272.5 \%$ & $298.5 \%$ & $319 \%$ \\
\hline $\begin{array}{l}\text { Profit Margin } \\
\text { Ratio: }\end{array}$ & & & & & & \\
\hline Net Profit Margin & $17 \%$ & $16 \%$ & $15 \%$ & $15.5 \%$ & $14.5 \%$ & $13.5 \%$ \\
\hline OPM & $23 \%$ & $22 \%$ & $22 \%$ & $20.5 \%$ & $19.5 \%$ & $19 \%$ \\
\hline $\begin{array}{l}\text { Gross Profit } \\
\text { Margin }\end{array}$ & $31 \%$ & $30 \%$ & $30 \%$ & $29 \%$ & $28 \%$ & $27.5 \%$ \\
\hline \multicolumn{7}{|l|}{ Rasio Solvabilitas: } \\
\hline $\begin{array}{l}\text { Debt to Capital } \\
\text { Asset Ratio }\end{array}$ & $42 \%$ & $43 \%$ & $41 \%$ & $32 \%$ & $31.5 \%$ & $31 \%$ \\
\hline $\begin{array}{l}\text { Debt to Equity } \\
\text { Ratio }\end{array}$ & $70 \%$ & $74 \%$ & $72 \%$ & $48.5 \%$ & $49.5 \%$ & $50 \%$ \\
\hline $\begin{array}{l}\text { Long Term Debt to } \\
\text { Equity Ratio }\end{array}$ & $16 \%$ & $17 \%$ & $20 \%$ & $13.5 \%$ & $13.5 \%$ & $15 \%$ \\
\hline
\end{tabular}

Sumber: Data diolah, 2014

\section{SIMPULAN}

Berdasarkan hasil analisis dan pembahasan pada bab sebelumnya, beberapa kesimpulan yang bisa diambil dari penelitian ini adalah hasil dari analisis rasio keuangan dapat diketahui bahwa kinerja keuangan anak perusahaan multinasional Jepang yang beroperasi di 
Indonesia ditinjau dari perspektif perusahaan induk Jepang pada perusahaan sub sektor ceramic, glass and porcelain pada tahun 2010 s/d 2012 adalah kurang sehat, karena tidak semua rasio dinyatakan tidak sehat, ada beberapa rasio yang dinyatakan lebih sehat. Oleh karena itu, hipotesis pertama yang menyatakan kinerja perusahaan anak perusahaan multinasional Jepang yang beroperasi di Indonesia ditinjau dari perspektif perusahaan induk Jepang adalah Sehat, ditolak. Hal ini dikarenakan kinerja anak perusahaan multinasional

Jepang yang beroperasi di Indonesia ditinjau dari perusahaan induk Jepang pada tahun 2010 s/d 2012, terdapat beberapa rasio keuangan yang tidak sehat, terutama dari rasio aktivitas dan rasio profitabilitas baik secara time series maupun cross section.

Pada hasil perhitungan rasio keuangan, tidak ada perusahaan yang lebih sehat, tetapi perusahaan yang memiliki kinerja lebih baik selama tahun $2010 \mathrm{~s} / \mathrm{d}$ 2012 adalah PT. Surya Toto Indonesia, Tbk. Oleh karena itu hipotesis kedua yang menyatakan bahwa kinerja keuangan anak perusahaan multinasional Jepang yang lebih sehat adalah PT. Surya Toto Indonesia, Tbk., ditolak. Hal ini dapat dilihat dari tolak ukur time series dan cross section. Berdasarkan time series dan cross section, PT. Surya Toto Indonesia, Tbk memiliki kinerja yang lebih baik dibandingkan dengan PT. Asahimas Flat Glass, Tbk.

\section{DAFTAR PUSTAKA}

Ambarwati, Sri Dwi Ari. 2010. Manajemen Keuangan Lanjut. Edisi Pertama. Graha Ilmu, Yogyakarta.

Arikunto, Suharsimi. 2006. Prosedur Penelitian Studi Pendekatan Praktik. Edisi Revisi Enam. PT. Rineka Cipta, Jakarta.

Brealey, A.R., Myers, C.S., Marcus, J.A. 2007. Fundamentals of Corporate Finance. The McGraw-Hill
Companies. Inc. USA.

Diterjemahkan oleh Bob Sabran. 2008. Erlangga, Jakarta.

Eiteman, D.K., Stonehill, A.L., Moffett, M.H. 2007. Multinational Business Finance, Eleventh Edition.Pearson Education, Inc. Diterjemahkan oleh Gina Gania. 2010. Erlangga, Jakarta.

Hariyana, Sigit Dani. 2012. Evaluasi Kinerja Keuangan Perusahaan Anak MNC Jepang yang Beroperasi di Indonesia dari Perspektif Mata Uang Induk. Fakultas Ekonomi dan Bisnis. Universitas Muhammadiyah Malang.

http://fadhilanalisis.blogspot.com/2011/10/ analisis-laporan-keuangan.html

http://www.academia.edu/4779867/Analisi s_pengaruh_kesadaran_perpajakan _sikap_rasional_lingkungan_sangsi _denda_dan_sikap_fiskus_terhadap kepatuhan. 10 februari 2014. $\underline{07.17}$

http://www.halojepang.com/kerjasamakebi jakan. 1 Desember 2013. 09.25

http://www.idx.co.id

Manasikana, Arina. 2008. Evaluasi Kinerja Perusahaan Anak MNC yang Bergerak Pada Sektor Tekstil dan Produk Tekstil di Indonesia Ditinjau dari Perspektif Perusahaan Induk. Fakultas Ekonomi dan Bisnis. Universitas Muhammadiyah Malang.

Sudana, I Made. 2011. Manajemen Keuangan Perusahaan Teori dan Praktik. Erlangga, Jakarta.

Sutrisno. 2009. Manajemen Keuangan Teori, Konsep dan aplikasi. Edisi Pertama. Ekonisia, Yogyakarta.

Tangkilisan, Hessel. 2003. Memahami Kinerja Keuangan Perusahaan: Aplikasi dan Analisis Balance Sheet. Balairung \& Co, Yogyakarta.

UNCTAD. World Investment Report. 2013 
Widyahartono, Bob. 2003. Belajar Dari Jepang: Keberhasilan Sebagai
Negara Industri Maju Asia. Edisi

Pertama. Salemba Empat, Jakarta 